\title{
Association between the polynoid Malmgreniella variegata (Polychaeta: Polynoidae) and Ophionereis reticulata (Ophiuroidea: Ophionereididae) first record to the Southeastern Caribbean
}

\author{
María Cecilia Gómez-Maduro ${ }^{1} \&$ Oscar Díaz-Díaz ${ }^{2}$ \\ 1. Postgrado en Ciencias Marinas Instituto Oceanográfico de Venezuela; cecilia_bmarina@hotmail.com \\ 2. Laboratorio de Biología de Poliquetos, Departamento Biología Marina, Instituto Oceanográfico de Venezuela; \\ ofdiazd@gmail.com
}

Received 12-XII-2016. Corrected 05-II-2017. Accepted 15-V-2017.

\begin{abstract}
The worms Malmgreniella variegata has been found as commensal of Ophionereis reticulata in Florida and Belize. Here we report the association in Playa Piscina (Arapo Islands), Venezuela. Rev. Biol. Trop. 65(Suppl. 1): S85-S91. Epub 2017 November 01.
\end{abstract}

Key words: Commensalism; Scale-worm; Symbiosis; Ophiuroidea; Venezuela.

There are numerous interactions in which polychaetes are involved; more than 290 species of these annelids, belonging to 28 families, have been referred by about 700 commensal relationships with various taxa as echinoderms $(36 \%)$, cnidarians $(20 \%)$, polychaetes $(17 \%)$, crustaceans $(13 \%)$, mollusks $(7 \%)$, sponges $(6 \%)$, while in the other interactions $(2 \%)$ involves nematodes, nemerteans, echiurids, sipunculids, bryozoans, foraminifera and balanoglosids, among others (Martin \& Britayev, 1998). Polynoidae family has the largest number of commensal species (55\%), and has been referred by Fauchald \& Jumars (1979) as a normal way of life. Many polynoid polychaetes have been reported living in close associations with other marine animals, including ophiuroids echinoderms (Millott 1953; Spooner, Wilson \& Tebble 1957; Devaney 1967, 1974; Gibbs 1969, 1971, 1972; Weston 1984; Pettibone 1993; de Santa-Isabel, Pinto-Cerqueira \& Souza-Alves, 1996; Granja-Fernández, Hernández-Moreno, \& Bastida-Zavala, 2013). In the Caribbean Sea, this relationship between Malmgreniella variegata (Treadwell, 1917) and Ophionereis reticulata (Say, 1825), has been recorded by Pettibone (Florida y Belize) but has never been registered for Venezuela and the southern Great Caribbean.

\section{MATERIALS AND METHODS}

This work is part of a study on the biodiversity of echinoderms of the northeastern region of Venezuela that has been done since 2014, covering eight localities from states Sucre: Quetepe (10²6'16”N - 64'01'39'W);

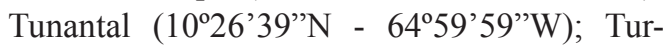
pialito $\left(10^{\circ} 26^{\prime} 40^{\prime \prime} \mathrm{N} 64^{\circ} 01^{\prime} 58^{\prime \prime} \mathrm{W}\right)$ (Gulf of Cariaco), and Arapo island $\left(10^{\circ} 15^{\prime} 44^{\prime \prime} \mathrm{N}\right.$ $\left.64^{\circ} 28^{\prime} 49^{\prime \prime} \mathrm{W}\right)$ and Larga islands $\left(10^{\circ} 21^{\prime} 23^{\prime \prime} \mathrm{N}\right.$ - 6420'59”W) (Mochima National Park) and Nueva Esparta: Cubagua (10 $48^{\circ} 14$ 'N - 64.13'00”W) and Margarita Islands $\left(10^{\circ} 57^{\prime} 48^{\prime \prime} \mathrm{N}\right.$. 64 $\left.4^{\circ} 10^{\prime} 46^{\prime \prime} \mathrm{W}\right)$ and Los Roques

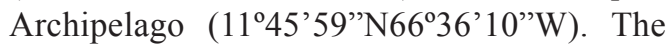
sampling was carried out by snorkeling in dead and live Millepora alcicornis Linneaus, 1758 (Cnidaria: Hydrozoa) colonies and rocks, from 0 to $3 \mathrm{~m}$ depth. When the associated polynoids-ophiuroids were detected, the organisms 
were carefully placed in plastic bags and transported in containers with cold seawater to the Laboratorio de Biología de Poliquetos-Instituto Oceanográfico de Venezuela. The relaxation, fixation, preservation and study of polynoids were performed according to the methodology described by Liñero-Arana \& Díaz-Díaz (2011), the polychaetes specimens were identified using the Pettibone (1993) and Salazar-Silva (2006) identification keys. Ophiuroid specimens were identified according to Fell (1960) and Hendler, Miller, Pawson \& Kier (1995). The ophiuroids and polynoids were deposited in the Colección de Referencia del Laboratorio de Biología de Poliquetos-Instituto Oceanográfico de Venezuela, Cumaná, Venezuela.

\section{RESULTS}

Two specimens of polychaetes identified as Malmgreniella variegata (Treadwell, 1917) were found associated with two specimens of the ophiuroid Ophionereis reticulata (Say, 1825). The association was found just in one of a total of eight localities of study. Malmgreniella variegata is a new record for Venezuela.

Family Polynoidae Kinberg, 1856

Genus Malmgreniella Hartman, 1967

Malmgreniella variegata (Treadwell, 1917)

Figures 1a-i, 2

Harmothoe variegata Treadwell, 1917:260, pi. 1: Figs. 17, 18; pi. 2: Figs. 1-3; Hartman, 1956: 251, 265, 273.

Paralepidonotus boholensis var. curacaoensis Horst, 1922:198.

Malmgrenia curacaoensis. Augener, 1927:45, fig. 2A-D; Kudenov, 1975:79.

Harmothoe lunulata. Millott, 1953:96, figs. 1, 2 [not Delle Chiaje, 1830].

Harmothoe sp. Hartley, 1987:156.

Malmgreniella variegata Pettibone 1993: 45-49, Figs. 28-31; de Santa Isabel et al. 1996: 137-142, Figs. 1-11; Martin \& Britayev,
1998; 16, Fig. 6E; Fauchald, Granados-Barba \& Solís-Weiss, 2009: 768; Salazar-Silva 2009: 458, 469, Fig. 4B; Hernández-Alcántara, Cortés-Solano, Medina-Cantú, Avilés-Díaz \& Solís-Weiss, 2014: 100.

Material examined. Two specimens on Ophionereis reticulata from Playa Piscina, Arapo Islands $\left(10^{\circ} 12^{\prime} 44^{\prime \prime} \mathrm{N}-64^{\circ} 28^{\prime} 45^{\prime \prime} \mathrm{W}\right)$, Sucre State, Venezuela (0 to $3 \mathrm{~m}$ depth).

Description. Two specimens complete, 14 and $18 \mathrm{~mm}$ long, 5 and $4 \mathrm{~mm}$ wide including chaetae, with 28 and 37 segments; 14 and 15 pairs of elytrae (Fig. 1a), respectively. Body elongated, flattened, broadest at midlength, gradually tapering posteriorly (Fig. 1a). Dorsum unpigmented anteriorly, posterior third with transverse diamond-shaped bands on each segment. Ventral surface with a medial longitudinal dark stripes and dark spots on each segment to bases of parapodia (Fig. 1b-c); and anteriorly on upper, lateral, and posterior lips of ventral mouth (Fig. 1b-c). Transverse ciliated bands on dorsum, two per segment, between elytrophores and dorsal tubercles. Fifteen pairs of elytra, oval, without tubercles nor papillae, with microtubercles near anterior borders, absent on first and some posterior elytra, with densely pigmented in some areas, extending medially to large semilunar pigmented regions and near lateral borders (Figs. 1d-e); these covering dorsum except for few posterior segments. Prostomium bilobed with anterior lobes truncate finely speckled with brown pigment, usually more dense along posterior margin; anterior lobes triangular, lacking distinct peaks; with two pairs of small, dark eyes, anterior pair just anterior to widest part of prostomium, posterior pair near posterior border. Ceratophores of lateral antennae inserted ventrally; styles subulate, with filiform tips. Ceratophore of median antenna inserted ventrally (Fig. 1f), converging midventrally and with ciliated ridge on ventral side, and short styles; Palps smooth, evenly tapering, 2-3 times as long as prostomium with longitudinal rows of minute papillae; tentaculophores each with small projecting 

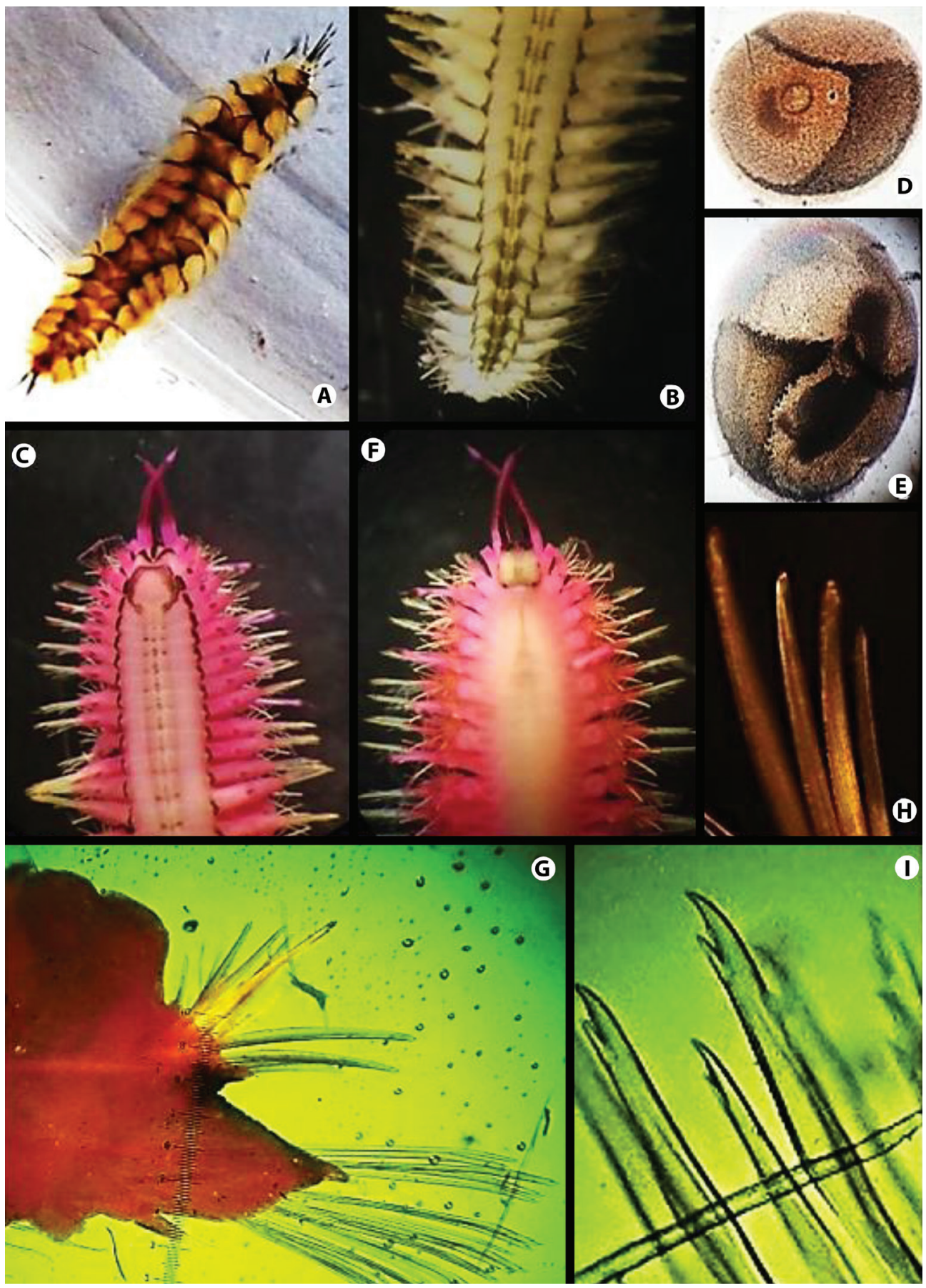

Fig. 1. Malmgreniella variegata a) complete specimen; b) posterior end, ventral view; c) anterior end, ventral view; f) anterior end, dorsal view; d) anterior end elytron; e) elytron form medium segment; g) parapodia elytrigerous; h) notochaetae; i) neurochaetae.

Fig. 1. Malmgreniella variegata a) ejemplar completo; B) extremo posterior, vista ventral; C) extremo anterior, vista ventral; F) Extremo anterior, vista dorsal; D) elytron de extremo anterior; E) elytron del segmento medio; G) parapodia elytrigerous; H) notochaetae; I) neuroquetas. 
acicular lobe on inner side, without chaetae, and pair of dorsal and ventral tentacular cirri similar to median antenna; all appendages variously pigmented (Fig. 1c, f). Median antenna and tentacular cirri similar in length, slightly shorter than palps, tapering to filiform tips, sparsely papillose with short, clavate papillae. Segment two with first pair of elytrophores, biramous parapodia, and ventral cirri with large cirrophores lateral to ventral and long styles similar to tentacular cirri (Fig. 1c). Parapodia biramous, with notopodia shorter than neuropodia; notopodium rounded with projecting acicular lobe on lower side; larger neuropodium with longer subconical, prechaetal acicular lobe with bulbous or digitiform supra-acicular process, with shorter, rounded postchaetal lobe (Fig. 1g). Notochaetae numerous, forming radiating bundle, stouter than neurochaetae, with numerous, faint, close-set spinose rows, shorter notochaetae with tapered tips, longer ones with blunt tips (Fig. 1h). Neurochaetae numerous, forming fan-shape bundle, with numerous, faint, close-set spinose rows, tapering distally to slightly hooked tips, all, except for some lower shorter neurochaetae, with secondary tooth (Fig. 1i). Dorsal cirri with cylindrical cirrophores and long styles extending beyond neurochaetae, with two dark bands near tip; dorsal tubercles nodular, ventral cirri short, tapered (Fig. 1g). Pygidium with anus between last pair of small parapodia, with pair of long anal cirri, color grading from darkly pigmented to colorless distal tips.

\section{DISCUSSION}

Ophionereis reticulata (Ophiuroidea: Ophionereididae) is one of the widely distributed species throughout the Caribbean; In Venezuela has been registered in Los Roques La Tortuga, Margarita and Cubagua island, Isla de Aves, Quetepe Beach, Tunantal Bay (Gulf of Cariaco), Mochima Bay; (Zoppi, 1967; Hernández-Ávila, 2010; Gómez-Maduro, 2012). According to Hendler et al. (1995), this species inhabits reef areas, mangroves and grassland meadows and its diet consists mainly of diatoms and algae filaments which it obtains through its tube feet.

In this study 85 specimens of $O$. reticulata were collected and only two of these were

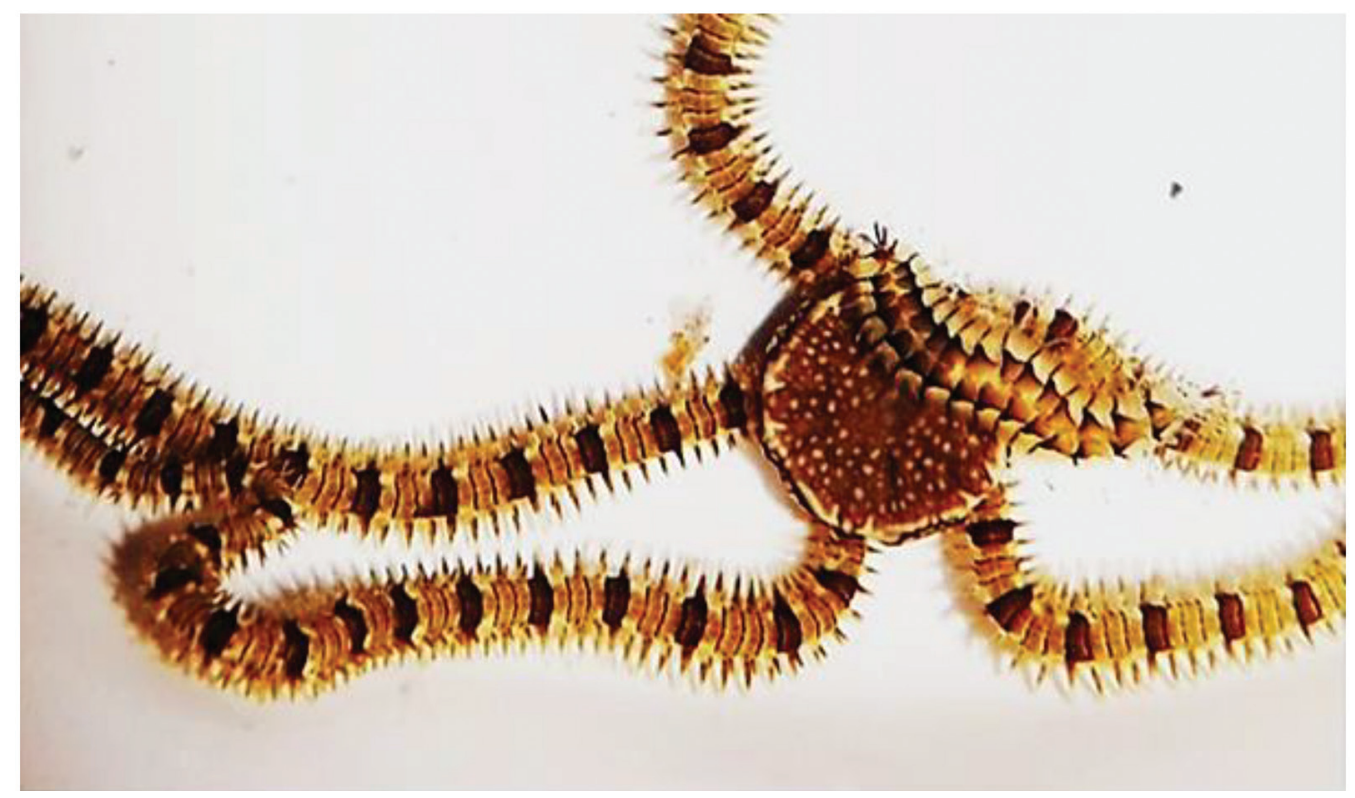

Fig. 2. Malmgreniella variegata and Ophionereis reticulata collected in Venezuela.

Fig. 2. Malmgreniella variegata y Ophionereis reticulata recolectadas en Venezuela. 
associated with the scale-worm $M$. variegata, so the prevalence of infestation $(2.3 \%)$ is the lowest compared to other ophiuroid-polynoid associations, which range from 5 to $100 \%$ prevalence (Hendler \& Meyer 1982; Alvà \& Jangoux 1989; Martin \& Britayev 1998; De Assis, Silva-Bezerra, de Brito, Isabelley-Gondim \& Christoffersen 2012; Granja-Fernández et al. 2013). Some studies has referred that the observed relationship between polychaetes/ ophiuroids is not fortuitous or due to chance, but Deheyn, Watson \& Jangoux (1998) pointed out that the infestation prevalences could be influenced by particular local and temporal conditions. But the data from this study are not sufficient to confirm any of these signs.

Millott (1953) described two polynoids, associated to Ophionereis reticulata (Say), found in sand beneath a submerged stone near Kingston, Jamaica, this polychaetes showed a color pattern matching closely that of the brittle stars (Fig. 2). Both, Millot (1953) and Pettinone (1993), reported that both $O$. annulata and $O$. reticulata, can be hosts of $M$. variegata, both ophiuroid species have similar pigmentations and color patterns and banded arms. This coloration allows them to go unnoticed in the host and is one of the aspects reported in the literature. In addition to M. variegata (Polynoidae), similar coloration patterns have been recorded for Gyptis ophiocoma (Hesionidae), Branchiosyllis exilis (Syllidae) and others polynoids, this camouflage capacity makes the presence of these polychaetes in the hosts almost (Handler \& Meyer, 1982; Martin \& Britayev, 1998).

Distribution. Intertidal to 7 meters. Northwestern Atlantic Ocean, off Florida, Caribbean Sea, Gulf of Mexico, Belize, Venezuela; Brazil, East Pacific Ocean, Gulf of Panama. GranjaFernández et al. (2013) records of scale-worms specimens from Western Mexico are probably a different species of Malmgreniella, as well as the host ophiuroid, Ophionereis annulata.

\section{RESUMEN}

Asociación entre el polinóide Malmgreniella variegata (Polychaeta: Polynoidae) y Ophionereis reticulata (Ophiuroidea: Ophionereididae) primer registro en el Caribe Sudeste. El gusano Malmgreniella variegata fue encontrado como comensal en Ophionereis reticulata en Florida y Belice. Aquí reportamos la asociación en Playa Piscina (Isla Arapo), Venezuela.

Palabras clave: Comensalismo; gusano escamoso; Ophiuroidea; Simbiosis; Venezuela.

\section{REFERENCES}

Alvà, V., \& Jangoux, M. (1989). Sur les symbioses entre Polychètes et Ophiures avec la description d'un nouveau cas de commensalisme. In: Régis MB, Segui A, Frasson C, Escoubet P, Riva A (eds) Echinodermes: actuels et fossiles. Actes du VI Séminaire International sur les Echinodermes, Aix-Marseille III: CERAM, Faculté des Sciences et Techniques de Saint-Jérôme, Foundation Océanographique Ricard, pp 185-192, Marseille, France.

Augener, H. (1927). Polychaeten von Curasao. Bijdragen tot de Dierkinde, Amsterdam, 25, 39-82.

De Assis, J.E., Silva-Bezerra, E., de Brito, R.J., Isabelley-Gondim A., \& Christoffersen M.L. (2012). An Association between Hesione picta (Polychaeta: Hesionidae) and Ophionereis reticulata (Ophiuroidea: Ophionereididae) from the Brazilian Coast. Zoological Studies 51(6), 762-767.

de Santa-Isabel, L.M., Pinto-Cerqueira W.R., \& de SouzaAlves, O.F. (1996). Associação entre Ophionereis reticulata (Say) (Ophiuroidea, Ophionereididae) e Malmgreniella variegata (Treadwell) (Polychaeta, Polynoidae) das Praias de Salvador, Bahia, Brasil. Revista Brasileira de Zoologia, 13(1), 137-142.

Deheyn, D., Watson, N., \& Jangoux. M. (1998). Symbioses in Amphipholis squamata (Echinodermata, Ophiuroidea, Amphiuridae) geographical variation of infestation and efect of symbionts on the host's light production. International Journal for Parasitology. 28, 1413-1424.

Devaney, D.M. (1967). An ectocommensal polynoid associated with Indo-Pacific echinoderms, primarily ophiuroids. Occasional Papers Bernice P Bishop Museum, 23, 287-304.

Devaney, D.M. (1974). Shallow-water echinoderms from British Honduras, with a description of a new species of Ophiocoma (Ophiuroidea). Bulletin of Marine Science, 24, 122-164. 
Fauchald, K., \& Jumars P.A. (1979). The diet of worms: a study of polychaete feeding guilds. Oceanographic and Marine Biology, 17, 193-284.

Fauchald, K., Granados-Barba, A., \& Solís-Weiss, V. (2009). Polychaeta (Annelida) of the Gulf of Mexico, Pp. 751-788 in D.L. Felder and D.K. Camp (eds.). Gulf of Mexico. Origin, Waters, and Biota. Volume 1, Biodiversity. Texas A\&M University Press, College Station, Texas.

Fell, H.B. (1960). Synoptic keys to the genera of Ophiuroidea. Zoological Publication Victoria University New Zealand, 20, 1-44.

Gibbs, P.E. (1969). Aspects of Polychaete Ecology with Particular Reference to Commensalism. Philosphkal Transactions of the Royal Society of London, B255, 443-459.

Gibbs, P.E. (1971). The polychaete fauna of the Solomon Islands. Bulletin of the British Museum (Natural History), Zoology, 21(5), 99-211.

Gibbs, P.E. (1972). Polychaete annelids from the Cook Islands. Journal of Zoology, London, 168,199-220.

Gómez-Maduro, M. C. (2012). Echinoderms of Tunantal Bay, Sucre state, Venezuela. Thesis in Marine Biology, Universidad de Oriente, $155 \mathrm{pp}$.

Granja-Fernández, R., Hernández-Moreno, P. \& BastidaZavala, R. (2013). First record of the association between Malmgreniella cf. variegata (Polychaeta, Polynoidae) and Ophionereis annulata (Echinodermata, Ophionereididae) in the Mexican Pacific. Symbiosis, 60, 85-90.

Hartman, O. (1956). Polychaetous annelids erected by Treadwell, 1891 to 1948 , together with a brief chronology. Bulletin American Museum of Natural History, 109(2), 239-310.

Hartman, O. (1967). Polychaetous annelids collectedly theUSNS ELTANIN and STATEN ISLAND cruises chiefly from Antarctic seas. Allan Hancock Foundation Monographs in Marine Biology. 2, 1-387.

Hartley, J.R. (1987). Taxonomic status of some species formerly referred to Malmgrenia Macintosh 1874 with the description of a new genus Lobopelma (Polychaeta: Polynoidae). The Beagle. Records of the Northern Territory Museum of Arts and Sciences, 4(1), 147-163.

Hendler, G., \& Meyer, D.L. (1982). An association of a polychaete, Branchiosyllis exilis, with an ophiuroid, Ophiocoma echinata, in Panama. Bulletin of Marine Science, 32:736-744.

Hendler, G., Miller, J.E., Pawson, D.L., \& Kier, P.M. (1995). Sea stars, sea urchins, and allies. Echinoderms of Florida and the Caribbean. Smithsonian Institution, Hong Kong.
Hernández-Alcántara, P., Cortés-Solano, D., Medina-Cantú, N.M., Avilés-Díaz, L., \& Solís-Weiss, V. (2014). Polychaete diversity in the estuarine habitats of Términos Lagoon, southern Gulf of Mexico. Memoirs of Museum Victoria, 71: 97-107.

Hernández-Ávila, I. (2010). Ofiuroideos (Echinodermata: Ophiuroidea) of the island of Cubagua, Venezuela. Work of Degree MSc Ciencias Marinas, Instituto Oceanográfico de Venezuela, Universidad de Oriente, $186 \mathrm{pp}$.

Horst, R. (1922). On some polychaetous annelids from Curacao. Bijdragen tot de Dierkunde (Amsterdam), Feest-nummer: 193-201.

Kinberg, J.G.H. (1856). Nya slägten och arter af Annelider, Öfversigt af Kongl. Vetenskaps-Akademiens Förhhandlingar Stockholm, 12 (9-10): 381-388.

Kudenov, J.D. (1975). Two new species of errant polychaetes from the Gulf of California, Mexico. Bulletin of the Southern California Academy of Sciences, 74(2): 75-80.

Liñero-Arana, I., \& Díaz-Díaz, O. (2011). Poliquetos de Venezuela I: Aspectos biológicos y ecológicos. Editorial Universitaria. $147 \mathrm{pp}$.

Martin, D. \& Britayev, T.A. (1998). Symbiotic polychaetes: review of known species. Oceanographic and Marine Biological: An Annual Review, 36: 217-340.

Millott, N. (1953). A remarkable association between Ophionereis reticulata (Say) and Harmothoe lunulata (Delle Chiaje). Bulletin of Marine Science of the Gulf and Caribbean, 3(2): 96-99.

Pettibone, M.H. (1993). Scaled polychaetes (Polynoidae) associated with ophiuroids and other invertebrates and review of species referred to Malmgrenia McIntosh and replaced by Malmgreniella Hartman, with descriptions of new taxa. Smithsonian Contribution to Zoology, 538:1-92

Salazar-Silva, P. (2006). Scaleworms (Polychaeta: Polynoidae) from the Mexican Pacific and some other Eastern Pacific sites. Investigaciones Marinas, 34(2):143-161

Salazar-Silva, P. (2009). Polynoidae Kinberg, 1856. En: J.A. de León-González, J.R. Bastida-Zavala, L.F. Carrera-Parra, M.E. García-Garza, A. Peña-Rivera, S.I. Salazar-Vallejo \& V. Solís-Weiss (Eds). Poliquetos (Annelida: Polychaeta) de México y América Tropical. Universidad Autónoma de Nuevo León, Monterrey, México, 737 pp.

Say, T. (1825). On the species of the Linnaean genus Asterias inhabiting the coast of the U.S. Journal of the Academy of natural sciences of Philadelphia, $5,141-154$ 
Spooner, G.M., Wilson, D.P. \& Tebble, N. (1957). Phylum Annelida. In Plymouth Marine Fauna, third edition, pages 109-149. Plymouth, England: Marine Biological Association of the United Kingdom.

Treadwell, A.L. (1917). Polychaetous annelids from Florida, Porto Rico, Bermuda and the Bahamas. Papers Department Marine Biology Carnegie Institute, Washington, 251: 255-272.
Weston, D. (1984). Family Polynoidae Malmgren, 1867. ln: J.M. Uebelacker \& P.G. Johnson (Eds). Taxonomic Guide to the Polyehaetes of the Northern Gulf of Mexico 3 (21): 1-39. Barry Vittor and Associates, Alabama, U.S.A.

Zoppi, E. (1967). Contribution to the study of echinoderms of Venezuela. Acta Biológica Venezuelica, 5: 267-333. 